This is an Accepted Manuscript of an article published by Taylor \& Francis in History of Retailing and Consumption on 21/03/2016, available online:

https://www.tandfonline.com/doi/full/10.1080/2373518X.2015.1135563 


\title{
The Geographical and Social Reach of the Eszterháza Gardens: Consumption of Nursery Plants in Hungary in the 1820s
}

\begin{abstract}
:
Although the famous Baroque gardens of Prince Nicolas Esterházy 'the Magnificent' (17141790) at Eszterháza were abandoned by his immediate successors and later given a more natural but rather modest appearance, the new pleasure ground was kept in good order to please the many tourists who were still interested in the so-called Hungarian Versailles. The Eszterháza gardens continued to play an important role in providing ornamental plants for other princely estates including the much-famed Eisenstadt, and also acted as a 'garden centre' for local society, distributing a wide range of fruit tree varieties and other garden products. During his leadership between 1821 and 1825, Court Gardener Anton Pölt (c. 17701836) kept a series of ledgers that reveal the entire trading business of the Eszterháza gardens. This exceptionally rare source recorded not only the species and cultivars of the nursery stock but the identity of buyers and their purchases as well. Analysis of the data sheds light on consumption habits, distribution range or social differences in the customs, and also provides information on high and low tides in the business or the reliability of the garden products in terms of revenue.
\end{abstract}

Keywords:

Landscape and garden history, plant consumption; Eszterháza and Eisenstadt, tree nursery, Anton Pölt 


\section{Introduction}

Upon the death of Prince Miklós (Nicolas) Esterházy 'the Magnificent' (1714-1790), the gardens of Eszterháza (today part of the township of Fertőd in Hungary) suffered a loss of care and attention. ${ }^{1}$ Only regular maintenance was carried out there during the short tenure of his son and successor, Prince Antal (Anthony) Esterházy (1738-1794), who as a soldier was occupied with the French Wars. The pompous court at Eszterháza, or the Hungarian Versailles as it was often referred to at the time due to its princely splendour and scale (Figure 1), was put on hold and many of its staff were released from service. The composer Joseph Haydn, who was the Kapellmeister at Eszterháza and already enjoyed international recognition, was allowed to travel abroad and pursue his career elsewhere. After Prince Antal's death, his son and successor Prince Miklós II Esterházy (1765-1833) transferred his court back to the original country seat of the family in Hungary, Kismarton, which is today Eisenstadt in Austria. He was an enthusiastic art lover and collector, ${ }^{2}$ who re-established the fame of his family as one of the leading figures in cultural life of the Habsburg Empire. He called Haydn back into active service and by tripling the original extent of the Eisenstadt gardens he created one of the most admired landscapes in the empire influenced by the then prevailing English theories of design.

At the same time, Prince Miklós II had the Eszterháza gardens simplified, the parterres grassed over, the basins and waterworks dismantled, the statues sold. ${ }^{3}$ By 1800 the grassed area of the former parterres, which were created in 1775 following the more than a century old structure of the Parterre du Nord at Versailles but also embellished with flower baskets according to a more recent French fashion, was embellished with foreign trees and shrubs in a more natural-looking manner that also required much less maintenance (Figure 2). More remote parts of the estate, on the other hand, like the once delightful groves in the Eszterháza woods or the pretty hunting lodge Monbijou, were left to grow over and the architecture to decay. The manor itself and the adjacent gardens were kept in good order; guests at Eisenstadt were often invited to a day excursion to have an impression of the prince's vast lands and many country houses, visiting the Pottendorf manor and garden in Lower Austria, or the Hungarian estates of the still famous Eszterháza and the princes' treasury at Fraknó Castle (today Burg Forchtenstein in Austria). Consequently, the Eszterháza gardens had to be maintained to an appropriate standard not to disappoint foreign dignitaries who visited them.

Despite no longer belonging to the principle mansion of the Esterházy princes, the Eszterháza gardens continued to play an important role in the princely household as providers of nursery plants for various other country house gardens of the princes, including frequent deliveries for the Eisenstadt pleasure grounds. Eszterháza was also a 'garden centre' for local society, distributing ornamental plants for country houses of the gentry and fruit tree varieties for a much wider audience among whom we can find peasants and the aristocracy alike. In addition to plants, the Eszterháza gardens also produced fruits that were regularly offered for purchase and the crops of the orangery found their way as far as Vienna.

This (and a wealth of other information) is sourced from a series of ledgers from the years between 1821 and 1825, kept by the then estate gardener at Eszterháza, Anton Pölt. Such sources are exceptionally rare. John Hooper Harvey's ground-breaking research identified many early British nurseries but he could rarely write about their customers due to the rarity of such records, despite being well aware that Britain is blessed with an abundance of horticultural sources compared to other countries. In his long series of publications on the topic the only two examples are a reference to a 115-strong customer list from 1730, with debts owned to a nurseryman but without the purchased goods, ${ }^{4}$ and a study on two nurseries in the northwest of England where ledgers survived ${ }^{5}$ it must be noted, on the other hand, that in the latter case, referring to a period between 1797 and 1811, all the buyers were of the rank 
of esquire and upwards, thus quite different from the varied landscape of customers at Eszterháza.

It was not unusual that private (i.e. non-commercial) nurseries sold plant material to the public from possibly as early as the end of the 17th century as examples of German estate nurseries show. ${ }^{6}$ Nevertheless, the topic is not well researched in the German-speaking realm, where Hungary culturally belonged during this period, as the introductory chapter of the first comprehensive yet recent publication on early German nurseries emphasises. ${ }^{7}$ The lack of background information makes it difficult to determine the role and impact of private nurseries compared to commercial, state-run or others. The only suggestion that is perhaps possible to make, is that plant lists of private nurseries seem to be proportionately better known, probably because of the more advanced record-keeping routines of grand estates compared to small commercial establishments. After his long series of articles on British nurseries, Harvey stated that pre-1840 stock lists of commercial nurseries are extremely rare even in Britain. ${ }^{8}$

There are a few case studies that reveal geographic influences of nurseries. Heike Palm's study on the royal nursery at Herrenhausen analyses cost free shipments of fruit trees within the Hanoverian kingdom between 1774 and $1797 .{ }^{9}$ This much earlier case, however, is also different as being an institutionalised effort to spread horticultural knowledge within an entire state. Angela Pfennig wrote on similar shipments of fruit trees and shrubs that the University of Greifswald sent to its own estates in Western Pomerania between 1810 and 1819. ${ }^{10}$ Although the period is very similar to that of the Eszterháza case, it is again an institutionalised plant transfer, and due to its corporate characteristics it can be more likened to the exchanges between the Esterházy estates, with the exception that only ornamental species were shipped from Eszterháza to other princely gardens.

Considering plant consumption on a personal scale, Heike Palm's allusion to lists of recipients deserves special attention: the royal Hanoverian nursery at Herrenhausen distributed foreign trees and shrubs as well as fruit trees to individuals between 1769 and 1779. ${ }^{11}$ However, recipients were selected individuals who enjoyed this privilege without any charge, thus cannot be described as customers. More pertinently for the Eszterháza case, plants were sold to any interested party in 1780 and 1781, but customer lists were not yet analysed. $^{12}$

The objective of this paper, therefore, is not only to introduce an early $19^{\text {th }}$ century private nursery and offer a fascinating insight into its entire business including its stock lists, customers and their purchases; but also to analyse the impact of the Eszterháza nursery on the plant consumption of local society and to detect how far, and which of, its products were delivered. It also aims to add to the scholarship on aristocratic seats as centres of knowledge transfer and on the wider pattern of the imitation of aristocratic lifestyle, explaining what extent this transfer and imitation can be applied to in the case of Eszterháza.

In doing so, three more - in some degree introductory - chapters will be necessary at the start in order to understand the findings presented in the two purely analytical chapters that follow. The first among the more detailed introductions deals with the relative prestige of the gardener's post at Eszterháza as being desired by many gardeners in more remote positions, but also as a comedown for those previously in charge at Eisenstadt. It also introduces Anton Pölt, his background and education to shed light on his status and skills. This is followed by a more thorough examination of his ledgers and the evaluation of their significance. The last of the exploratory chapters describes the stocks themselves, analysing their origin, extent and merit. The two following chapters explore the consumption of the garden products on the one hand and the pattern of purchases on the other, concluded by further remarks on the relevance of the Eszterháza case. 


\section{Gardeners at Eszterháza}

Due to the persisting international fame of the once magnificent princely display of Eszterháza, the estate gardeners there remained among the better-trained professionals of the Esterházy establishment, with the title Court Gardener (Hofgärtner), which was enjoyed only by some estate gardeners at the prince's more important country houses. It cannot be surprising therefore that following the death of Court Gardener Ludwig Engel at Eszterháza on the $8^{\text {th }}$ May 1821, there were as many as four other people who applied for the position. All four of them were or had been estate gardeners of other Esterházy seats not far from their desired post. ${ }^{13}$ They all must have been disappointed to learn that the job was given to Anton Pölt (c. 1770-1836), ${ }^{14}$ son of the Princely Head Gardener Mathias Pölt (c. 1744-1810), ${ }^{15}$ although he might not even have applied for it, or at least his applications cannot be found in the archives. He was responsible for the sales of nursery and other garden products in Eszterháza that is the subject of this paper.

Anton Pölt was elevated to the Court Gardener status at Eisenstadt at the beginning of 1803 when production gardening was separated from the landscape gardening duties. His father remained responsible for the landscaping while Anton Pölt was put in charge of orchards and kitchen gardens, as well as the construction and arrangement of the new forcing houses. ${ }^{16}$ To further improve his abilities he was sent to Britain for a year-long study tour from June 1804 to August 1805. (His reports on his travel to and from London reveal the Continental gardens he visited en route, ${ }^{17}$ but his stations in England, Scotland and Wales are yet unknown.) After his return he was stationed in Eisenstadt and continued to be in charge of the conservatories and forcing houses there. A year later another new Court Gardener was called in to oversee the development of the English garden of Eisenstadt, the aforementioned Ludwig Engel.

This situation caused tensions between the two Court Gardeners, which rose to such a degree that Prince Miklós II had to intervene. ${ }^{18}$ Pölt was consequently removed from view and given the Eszterháza post (for the first time) with the title 'Adjunct Head Gardener' and a pay rise from August 1808 onwards. However, when his father died two years later, the Head Gardener (Obergärtner) position was given to his arch-rival Ludwig Engel. Despite all this, Engel was soon transferred to the aforementioned Pottendorf whilst retaining his newly acquired title, and by the middle of 1811 the most important post (landscape gardener) at Eisenstadt was given to Court Gardener Anton Niermayer. Pölt's tenure subsequently ended in Eszterháza and he was called back to Eisenstadt ${ }^{19}$ where he continued to hold a Court Gardener position for 'edibles gardening' (Hofzehrgärtnerei) ${ }^{20}$

The Eszterháza estate gardener post then was given to Franz Pölt (c. 1777-1845), ${ }^{21}$ a brother of Anton, who held it for three years. In 1814 it was Engel's term to serve in Eszterháza until his death in May 1821. Anton Pölt replaced him, as explained above, until September 1825 when Franz Pölt returned to carry on until his own retirement in $1843 .^{22}$ The reason for Anton Pölt's discharge might have been connected to an earlier visit of the prince to Eszterháza in 1824, most likely with his English and Hungarian hunting guests at Eisenstadt in November of that year, when he found the state of the Eszterháza gardens less than satisfactory. ${ }^{23}$ Anton Pölt was perhaps pensioned or at least was not in charge any longer after 1825. He died in Eszterháza on the $21^{\text {st }}$ July in $1836 .{ }^{24}$

\section{Pölt's Ledgers}

A well-stocked nursery came under Anton Pölt's care and supervision when he took over the post at Eszterháza as he was able to sell both exotic foreign species and sought after fruit 
varieties right after his arrival. The proof of this is the books of the sales he kept between 1821 and 1825 (Figure 3), not only recording the sold stocks but also the name of buyers and their purchases in detail. ${ }^{25}$ His - or, perhaps, his superiors' - purpose was to learn and show how much profit could be obtained for the benefit of the estate. The gardener at the nearby hunting lodge of Monbijou, who was one of the self-appointed candidates for the Eszterháza position, also prepared inventories of his gardening tools and materials (but no stock) between 1821 and 1825. This might have been the command of Anton Pölt who probably exercised some kind of authority over the Monbijou garden as well. An 1814 inventory tells us that there was another nursery of fruit trees at Monbijou, ${ }^{26}$ so its stocks were probably also sold by the Eszterháza estate gardener.

Nevertheless, the nursery was not a commercial establishment in the first place: the available products were the surplus that were not needed for the princely household or estate, and were sold under the supervision of the financial officers, and as far as fruit trees were concerned, to the highest bidder. The most important task of the nursery was to produce ornamental plants en masse for other estates of the prince, primarily for Eisenstadt.

The five-year series of ledgers is an extraordinary source for several reasons. Not principally because it provides proof of a vivid history of Eszterháza's traditionally ignored $19^{\text {th }}$ century gardens; the estate gardening organisation was indeed abolished in $1862,{ }^{27}$ along with the lease of the entire estate and other desperate measures to keep the Prince Esterházy heirloom free from bankruptcy that eventually befell in 1865, and it was not set up again until the revival of the manor at the turn of the $20^{\text {th }}$ century. Nevertheless, it is fascinating to learn that Eszterháza still played a vital part in the horticultural establishment of the Esterházy princes following their departure after 1790. The ledgers also give information about plant transfers to Eisenstadt, the primary seat of the Esterházy princes that time, thus telling us more about plant use in the famed gardens there.

Another, more important, aspect of Pölt's sales books lies in the fact that they are one of the very few sources that offer an insight into the stock and prices of an estate nursery in historic Hungary; although it is not certain that buyers purchased from every plant variety that was available there, the Eszterháza nursery with its nearly fifty ornamental trees and shrubs along with more than sixty fruit varieties had a fairly substantial material in any case. There are only a few other establishments that could serve as comparison. The extensive nature of the nursery at Vöröskő Castle (today Červený Kameň in Slovakia) of Count Rudolf Zichy can only be judged by its mid- $18^{\text {th }}$ century plan, but, disappointingly, this much earlier example of an estate nursery does not provide information of the stock because the legend of the plan, which should contain the list of plants corresponding with the numbers on the drawing, did not survive. ${ }^{28}$ There are some records on plant exchange between estate gardeners of aristocratic country seats but due to the usually very short plant lists they offer only a glimpse. Count Festetics possessed a printed catalogue of nursery plants sold by the Prince Liechtenstein estate nurseries of Moravia and Lower Austria, specially hand-amended and prepared for his gardens at Keszthely in 1814, but there is no proof that he made any purchases from there. ${ }^{29}$

The sole example comparable to Eszterháza is the Gyöngyösapáti nursery at the manor of Count Pál Széchényi (1789-1871) ${ }^{30}$ founded in the 1810 s, that in 1823 even published a catalogue of its products offered to the public. ${ }^{31}$ This act clearly shows an effort to find customers for nursery products, which were far more numerous than at Eszterháza at the very same period: apple varieties alone numbered nearly 300, and together with more than 200 pear and numerous apricot, peach, cherry and plum cultivars they amounted to more than 700 fruit varieties. However, no doubt due to the scarcity of sources, no study has been so far dedicated to pre-1850 Hungarian nurseries, and the Gyöngyösapáti nursery of Count Széchényi remained unnoticed along with the one at Eszterháza. 
But the real significance of Pölt's records is that they reveal the identity of those who purchased from the nursery and even tell us what goods exactly they bought. It has been long known that favoured plants somehow found their way from princely grounds to more modest gardens in their neighbourhood, but besides personal connections between staff and locals, or theft as a very obvious mean to acquire plants, there was a direct way of giving them away for money. There are around 130 names in Pölt's records representing all classes of society. Most of them were either princely officers from a very wide range of ranks and professions or craftsmen of all kinds like baker, butcher, furrier or joiner. There were noblemen, even a count among them, and other men and women of appreciation who were simply styled 'Mister' or 'Mistress' (H. for Herrn or Frau in Pölt's German records), but there were people without any distinction, mostly from the local Hungarian peasantry. (The leader of the neighbouring village was also recorded without style, being a peasant himself.) These details make Pölt's records an exceptionally rare source, and even unique as far as Hungarian garden history is concerned. They give an unprecedented opportunity to investigate consumption habits between different layers of society as their way of spending was based on their status and geographical distance. The horticultural demands of the local population disclose the choicest plants and choosiest clients.

\section{The Nursery Stock and its Origins}

The stock itself deserves a more thorough investigation. Its origin can in part be traced back to the $18^{\text {th }}$ century heyday of Eszterháza, namely plants from the orangery, and possibly an unknown portion of fruit varieties as well as ornamental species. Orangery plants, however, were not for sale or were not desired by customers, as there was not one single purchase of them. Their fruits, on the other hand, were sold regularly, and based on their number that reached several hundreds and sometimes thousands per year, they formed a fairly substantial collection, despite many of them having been transferred to Eisenstadt earlier. There were at least six different kinds of citrus trees that bore edible fruit, although there might have been more ornamental varieties as well.

Not only were the otherwise locally unavailable orangery fruits sold, but the orchard also produced enough for outsiders. Peaches especially were sold in hundreds at the premises, but Pölt was also able to sell apples, pears, apricots, redcurrants and grapes, and an everincreasing number of figs were sold in the last three years of the records. Apples and pears were sometimes sold by their distinctive varieties that were numerous in Eszterháza, representing one of the main assets of the gardening unit.

Trees of many fruit varieties must have been present during the $18^{\text {th }}$ century to provide diverse enjoyment for the princely household. Pölt was able to sell apricot, sweet as well as sour cherry, peach, walnut and plum trees, along with the numerous apple and pear varieties. The latter ones were not cutting edge new selections but long established cultivars, so it is quite possible that they were already present in Eszterháza decades before. This perhaps explains why Pölt could sell only one or two of any apple variety per year, and pears were also sold in ones or twos in most cases, although occasionally they were somewhat more sought after. Whereas these were perhaps bought for back yards, more ordinary fruit trees in larger quantity could have been destined for orchards. Pölt's apple and pear names are sometimes precise enough for identification (like the Bezi de la Motte pear) but often cover larger groups of cultivars (like the Reinette apple). It is doubtful whether the following varieties could be still found in Eszterháza or in the neighbouring villages. But any positive match with the names on this list would almost certainly mean the survival of the stock of the Eszterháza nursery: 


$\begin{array}{ll}\text { apples: } & \text { Bloner } \\ \text { Api } & \text { Bon chretien } \\ \text { Bogatsch } & \text { Colmart } \\ \text { Calville } & \text { Dukaten } \\ \text { Autumn Calville } & \text { Frauen } \\ \text { Sour Calville } & \text { Big Frauen } \\ \text { Magdalena } & \text { Haber } \\ \text { Pepin d'Or } & \text { Isenbart } \\ \text { Reinette } & \text { Jakobi } \\ \text { French Reinette } & \text { Kaiser } \\ \text { Yellow Reinette } & \text { Kirsch } \\ \text { Golden Reinette } & \text { Lorenzi } \\ \text { Gray Reinette } & \text { Magdalenen (Madeleine) } \\ \text { Red Reinette } & \text { Marzanini (Marganini?) } \\ \text { Roßmarin } & \text { Motte } \\ \text { Streifling } & \text { Muskateller } \\ \text { Taffet } & \text { Nagowitz } \\ \text { Weinlinger } & \text { Pomeranzen (Summer Pomaranzen?) } \\ \text { Spanish Weinlinger } & \text { Riss } \\ & \text { Ruschlet (Rousselet/Rousselette) } \\ \text { pears: } & \text { Salzburger } \\ \text { Augst } & \text { Early Salzburger } \\ \text { Bergamotte } & \text { Round-shaped Salzburger } \\ \text { French Bergamotte } & \text { St. Germain } \\ \text { Dutch Bergamotte } & \text { Virgouleuse } \\ \text { Striped Bergamotte } & \text { Waiz } \\ \text { Bezi de la Motte } & \text { Zapfen } \\ & \end{array}$

It is tempting to think that as far as the so-called exotic species of the Eszterháza nursery were concerned they came from the organised plant import of Prince Miklós II. He was one of those continental grandees who used the services of the 'botanical and horticultural agent ${ }^{\prime 32}$ John Hunneman (who died in 1839 and was based at 9 Queen Street, Soho, London ${ }^{33}$ ). Hunneman was also the agent of Prince Esterházy from at least 1816 and responsible for several plant transports to Eisenstadt in the following years. ${ }^{34}$ According to John Claudius Loudon, chief horticultural correspondent and authority of his age, "the collections which have been formed in Germany [including Hungary], during the last 50 years [between 1785 and 1835], have, for the most part, been either procured direct from Hackney [the Loddiges' nursery], or from German nurserymen who have purchased their foreign trees and shrubs there. ${ }^{\prime 35}$ Loudon's words are true even if continental garden patrons often turned to another much famed London nursery, namely that of Lee \& Kennedy's, as an alternative source of plant material. So did Prince Miklós II in the $1820 \mathrm{~s}$ as his other port of plant acquisitions, ${ }^{36}$ although in the $18^{\text {th }}$ century the Princes Esterházy obtained foreign plants mostly from Vienna where nurserymen were indeed probably better connected with Loddiges. Nevertheless, Loudon himself praised Lee \& Kennedy's nursery as being "for many year[s]... deservedly considered the first in the world", ${ }^{37}$ and Prince Miklós II (having had direct connections with Britain for he visited it several times and even acted as Ambassador Extraordinaire to the Court of St. James, but more importantly through his son, Prince Pál Antal (1786-1866) who was Ambassador of the Austrian Empire in London for decades) was well acquainted with the importance of Lee \& Kennedy's. The third obvious source of new plants was the much-famed nursery of Louis-Claude Noisette (1772-1849) in Paris ${ }^{38}$ for the prince employed a member of 
the Noisette family, arguably Louis-Claude Noisette himself, to a newly created Court Gardener position at Eisenstadt in $1808 .{ }^{39}$ Louis-Claude Noisette later supplied plants to Eisenstadt from Paris in the 1820s. Besides these three sources the prince occasionally obtained plants from other foreign suppliers across Europe.

Nevertheless, a large part of the foreign trees in Eszterháza were not from the most recent acquisitions (although new species arrived there during Pölt's tenure and it seems probable also during Engel's time). Most foreign trees and shrubs at Eszterháza probably originated from Viennese nurseries, and were either already imported by Prince Miklós I 'the Magnificent' when he had a small English garden created in the Eszterháza groves in the mid1780s or transported from Eisenstadt in 1800 when the parterre was grassed over and planted with exotic species. ${ }^{40}$

The 1814 inventory of the Eszterháza gardens ${ }^{41}$ specifically refers to the exotic plants of the parterre (or rather the pleasure ground) as mother plants of the nursery. Based on the inventory it must be noted that not all plants were used for producing nursery stock, or at least many species were not sold during Anton Pölt's tenure, although there were many attractive plants among them: ${ }^{42}$ Broussonetia papyrifera (paper mulberry), Catalpa bignonioides (Indian bean tree), Coronilla emerus (scorpion senna), Gleditsia triacanthos (honey locust; although Pölt always writes G. horrida - present name: G. japonica - in his sales books), Cornus alba (red-barked dogwood), Hypericum hircinum (stinking St John's wort; there is probably a mistake in the 1814 inventory that writes Hi[e] racium hircinum instead, which does not exist, and elements of the name may refer to orchid species), Lycium barbarum (Chinese box thorn), Populus balsamifera (balsam poplar), Potentilla fruticosa (shrubby cinquefoil), Spiraea chamaedryfolia (elm-leaved spiraea), Spiraea hypericifolia (Italian may), Spiraea salicifolia (bridewort), Staphylea trifolia (American bladdernut) and Viburnum opulus 'Roseum' (snowball).

The nursery itself laid to the west of the pleasure ground (Figure 2), and the latter stretched to south from the main facade of the manor. The nursery formed part of the western walled gardens that were created during the time of Prince Miklós I 'the Magnificent'. Walled kitchen gardens and orchards occupied the area on both sides of the parterre in the $18^{\text {th }}$ century and they were still being used as such in later periods. But the nursery must have gained even more importance after Antön Pölt's tenure, as an 1845 map by the princely surveyor Ignác Szakonyi ${ }^{43}$ shows that the entire western kitchen garden was used as a nursery for exotic species; hence the map was drawn for the purpose of relocating the nursery from its then present location to a more remote area of the estate with the indication that its area could be used again for kitchen gardening ('Die alte Exotische-Baumschule, ebenfalls zu einer neuen Gemüse Garten verwendbar').

Fruit trees were trained along the walls of the kitchen gardens but also stood freely in both of them. The orchards proper lay further east, adjacent to the eastern walled garden. There were not specific gardens dedicated to individual fruit species or cultivars, they were rather mixed up across the production gardens of the estate, thus giving opportunity to obtain cuttings from anywhere.

This appears to be in contrast to the foreign trees and shrubs that all came from the area of the former parterre. However, Pölt's sales books show a discrepancy between the plants of the pleasure ground and those of the nursery: there were species in the nursery that were not listed at the pleasure ground. A partial solution to this discrepancy is that there was another pleasure garden laid out within the eastern kitchen garden, according to the 1814 inventory, listing another series of ornamental species, although with some overlapping with the pleasure ground. This garden was certainly laid out in an informal manner and contained some plants that appear in the nursery stock but not in the pleasure ground. Nevertheless, this garden also had plants that were not utilised to produce nursery stock, like Acer variegata (an 
unidentifiable maple species with white or yellow striped/spotted leaves), Amorpha fruticosa (bastard indigo), Cornus amomum (silky dogwood), Platanus orientalis (oriental plane) or Pyracantha coccinea (firethorn).

There are still some plants that are not listed anywhere in the 1814 inventory although Pölt was able to sell them from the Eszterháza nursery. Those remaining missing plants must have come to Eszterháza during Engel's tenure between 1814 and 1821, or perhaps during Pölt's own term without being recorded. Even discounting the ornamental plants that were not propagated, this is an impressive list for an estate nursery that was not designed for commercial purposes:

Acer campestre (field maple) Acer negundo (boxelder maple) Acer platanoides (Norway maple) Acer pseudoplatanus (sycamore maple) Acer tataricum (Tartarian maple) Aesculus hyppocastanum (horse-chestnut) Caragana arborescens (Siberian peashrub) Celastrus scandens (American bittersweet) Celtis australis (European nettle tree)

Cercis siliquastrum (Judas-tree)

Colutea arborescens (bladder senna)

Cytisus hirsutus (hairy broom)

Elaeagnus angustifolia (silver berry) Gleditsia japonica (Japanese honey locust)

Hibiscus syriacus (rose mallow) Juglans regia (common walnut) Koelreuteria paniculata (goldenrain tree) Laburnum anagyroides (common laburnum) Lembotropis nigricans (black groom) Lonicera caprifolium (goat-leaf honeysuckle) Lonicera sempervirens (coral honeysuckle) Lonicera tatarica (Tartarian honeysuckle) Ononis fruticosa (srubby restharrow)
Periploca graeca (silk vine)

Philadelphus coronarius (sweet mock-orange) Platanus occidentalis (American plane tree)

Ptelea trifoliata (hop tree)

Rhamnus cathartica (purging buckthorn)

Rhamnus frangula (alder buckthorn)

Rhus glabra (smooth sumach)

Rhus radicans (poison ivy)

Rhus typhina (staghorn sumach)

Robinia pseudoacacia (black locust)

Robinia pseudoacacia forma sophorifolia (small-leaved black locust)

Robinia viscosa (clammy acacia)

Salix babylonica (weeping willow)

Sambucus racemosa (red-berried elder)

Spartium junceum (Spanish broom)

Physocarpus opulifolius (ninebark)

Symphoricarpos albus (snowberry)

Syringa persica (Persian lilac)

Syringa vulgaris (lilac)

Thuja orientalis (biota)

Trema orientalis (charcoal tree)

There do not seem to be supplies to Eszterháza from external sources during Pölt's tenure, which hints that everything was produced from the plants already present. However, planting of the Eisenstadt garden required thousands and thousands of ornamental trees and shrubs, which the Eszterháza nursery could not cope with in the long run, and thus needed extra stock. This arrived in the form of seeds at the end of 1824 and in large quantity, volumes ranging from around half a litre to nearly hundred litres. ${ }^{44}$ Besides the roughly twenty varieties already present, some new species arrived in Eszterháza like Celtis occidentalis (common hackberry), Cytisus albus (white Spanish broom), Fraxinus americana (white ash) or perhaps Fraxinus nigra (black ash), ${ }^{45}$ Hippophae rhamnoides (sea buckthorn), Juglans cinerea (butternut), Juniperus virginiana (red cedar), the mysterious Ratenus auerifolius (?), Robinia pseudoacacia var. inermis (spineless black locust) ${ }^{46}$ and Sorbus aucuparia (rowan).

Fruit trees were not brought to Eszterháza between 1821 and 1825. The only exception is an April 1825 transfer of 97 plum and 240 apple trees from Eisenstadt. They were all uniformly shaped in a pyramid style and not distinguished by cultivar, which suggests that they were for the princely orchards and not for sale. Later in 1825 along with dozens of young vine plants, seven chrysanthemums (Anthemis artemisiifolia in the Esterházy correspondence) 
were sent from Eisenstadt to Eszterháza no doubt to embellish the pleasure grounds.

It seems, therefore, that during his office time Pölt had to rely on the stocks already in Eszterháza and only in the last year could he produce nursery plants from external sources. It would certainly prove his ability to keep the nursery afloat but there are few clear trends in his business activity. There were several setbacks in the income and some departments of the gardening division showed unsteady performance. Similarly, the geographical and social reach of Pölt's nursery had only a few, albeit important, tendencies.

\section{The Retailing of Garden Products}

The nursery had two major sources of revenue. One of them was from the individuals who bought garden products. They had very diverse social background and were from various geographic locations, as it will be explained below. The other, almost always more profitable source was from other princely estates and offices. These latter bought trees and shrubs only for landscape gardening and afforestation, with the occasional exception of fruits and vegetables delivered for the prince himself when travelling through Eszterháza en route to or from his South Transdanubian hunting lodge and game park in Ozora. There was a kind of giro system in use among the Esterházy estates and offices that helped track their income and expenditure; it is unlikely that cash changed hands during these internal affairs.

There were four different product ranges of the Eszterháza gardens offered for individual customers (Table 1). Fruits of the orchards are one of them as an obvious source of income. Obviously they were sold for locals or for nearby residents. The months of July, August and September were mostly about selling fruits from the garden, starting with apricots, then figs, peaches, and finally apples and pears. They were all sold on a set price throughout the season, and by volume. Figs and peaches were sold by the piece, and differences in the price of peaches occasionally occurred based on the size or appearance within the season. Apricot was priced according to the season, for example the usual price of apricot was doubled in 1823 and 1825 that must have been due to the unfavourable circumstances resulting in bad harvest. It was probably the case again in 1824, too, when no apricots were sold at all. Orchard fruits contributed very modestly to the revenue of the gardens, with varying results.

The other range of fruits were the fruits of the orangery. Citrus fruits were the biggest hit from the gardens in the first year, and remained a reliable crop throughout, usually sold from October to December. In 1821 and 1824 the income from orangery fruits outmatched even the sales of fruit trees. Quite contrary to orchard fruits, citruses were taken or sent to the furthest locations from Eszterháza. There were only two customers from more than one hundred kilometres from Eszterháza, and they bought nothing but orangery fruits from there. These two people could be regarded as the two distinctive types of citrus buyers. One of them is a Franciscan monk from Komárom (today Komárno in Slovakia) who bought six oranges in 1824. He was the type of the gentleman buyer as only well-to-do people bought citrus fruits and even they did in small quantities in most cases. They were mostly noblemen and higherranking officers of the Esterházy establishment, occasionally craftsmen who could afford it. The parish priest of a neighbouring town was a regular customer.

A Viennese pastry baker represents the other type of customer who bought orangery fruits, sometimes in hundreds, to make a profit on them. They were quite numerous, like several tradesmen and innkeepers from the royal free town of Sopron, or a lacquerer and painter from the same town who probably bought them for some commercial use in his trade. Certainly commercial use motivated the custom of pastry bakers too, one of them from Sopron and the other being the already mentioned Viennese craftsmen who lived over a hundred kilometres from Eszterháza. The latter one purchased 2000 limes and 300 bitter 
oranges besides other fruits in 1825 that put him in the second in the list of high spending customers at Eszterháza. The remaining orangery fruits were sold in hundreds on the square in Sopron to the townsfolk, just days before Christmas every year, making handsome revenue for the Eszterháza gardens.

Nonetheless, Pölt's skills as an orangery gardener are perhaps questionable. He took more than 35 orangery trees from one Marodeur (it must be a French name because it was written with Latin characters as opposed to the rest of his German text of the usual Gothic letters) on the last day of June in 1821. At the beginning of the next year he reported that six of them died. Two years later an additional two died, again at the beginning of the year. In his last inventory he stated that out of the seven pomegranate trees (Punica granatum) that he took over in 1821 in bad condition, apparently as part of the Marodeur orangery, five died during the course of 1825 . It means that a third of the former Marodeur orangery died under Pölt's supervision. Also, the sale of orangery fruits saw a sharp decline after the first year, although numbers started to slowly climb up again after that.

The third range of products of the Eszterháza gardens came from the nursery and was the most profitable of all: the fruit trees. They were always sold to the highest bidder with the exception of a one-time sale of dwarf apricots and peaches, high stem plums, sweet and sour cherries in March 1824, when dwarf trees were offered for 30 and high stems for 45 kreutzers, regardless of the species. The set price suggests that they were standardised products as opposed to all other fruit trees. There were only four buyers for them, two princely estate officers from the rather distant Léka (today Lockenhaus in Austria), the parish priest from Mosonszentpéter ${ }^{47}$ and a nobleman from the neighbouring Fertőszentmiklós.

All the other fruit trees were offered in various sizes and perhaps other qualities, which resulted in a wide range of prices. This also means that products were not trained to the same standard but rather seen as individual specimens with different potential. There were a few days in the year, usually starting in July and lasting until September, when individuals could go to Eszterháza and bid for specimens. Apple and pear trees were sold individually; very occasionally the lot comprised two trees. Less valued trees such as walnuts or plums were often sold in twos or threes per lot, sometimes even more. Prices varied enormously, the lowest price on any apple or pear being $13 \mathrm{x}$ (kreutzers) and the highest $10 \mathrm{Fl}$ (guldens), which means a nearly 50 -fold difference. ${ }^{48}$ This difference does not seem to be related to the rarity or supposed value of a specific cultivar because many of them showed similar extremes. A typical auction day was on the $4^{\text {th }}$ September 1822 when 30 lots of apple and pear trees were on offer amounting to 37 trees altogether, plus 8 lots of walnut trees numbering 32 trees. It was the fourth and biggest auction in that year bringing in $71 \mathrm{Fl} 25 \mathrm{x}$ alone, the others being on the $1^{\text {st }}$, on the $17^{\text {th }}$ and on the $31^{\text {st }}$ of July. By contrast there was only one auction in the quiet year of 1824 when in early October only a few apple and pear trees and some walnut trees were sold.

As fruit trees were not standardised at Eszterháza, comparison with the prices of other establishments would be uninformative, not to mention that the scarcity of sources and the general lack of scholarship on the topic makes any comparison very difficult. It is nevertheless important to take a look at the possibilities of plant purchase in the country, which could have competed with Eszterháza.

In the royal free town of Pest (today part of Budapest), being already the commercial capital of the country by that time, three leading seedsmen were in business and basically responsible for providing seeds in great quantities for even the most remote parts of the country. One of them, Johann Christian Hassenstab also founded a nursery where his 1822 catalogue listed as many as 31 sour and sweet cherry varieties, 28 different plums, 20 peach, 5 apricot, 175 apple and 141 pear varieties. In the beginning of 1824 he sold 2000 fruit trees to the public. The other important seedsman, Franz Mayr, who, like Hassenstab, started his 
business around 1810, also held numerous ornamental trees and shrubs as well as fruit varieties, but he published seed catalogues only. ${ }^{49}$ Regrettably, as product prices from these establishments are yet unbeknown to us, they cannot serve for comparison. Moreover, the Austrian state bankruptcies of the $1810 \mathrm{~s}$, the consequent devaluations of the currency and the inflation that characterised the period make earlier priced plant catalogues of little use. ${ }^{50}$ The financial system finally stabilised in the $1820 \mathrm{~s}$, but again, there are very few price lists for comparison. The aforementioned 1823 catalogue of the Gyöngyösapáti nursery leaves the lines for the set prices blank in the publication. ${ }^{51}$

Possible buyers could also look further and use home delivery services, for they already existed at foreign nurseries, if perhaps not at Hungarian ones, and they were available for Hungarians, too. One of the prominent pomologists of his time, Georg Liegel listed his nursery items in his excellent book on fruits, published in 1825 and thus coinciding with Pölt's tenure at Eszterháza, that could be delivered from his nursery in Braunau am Inn, a small Austrian town at the Bavarian border. ${ }^{52} \mathrm{He}$ did not give specific figures but price ranges instead, for example high stem apples cost between 5 and 20 kreutzers or dwarf apricots between 15 and 30 kreutzers. As he specialised in acquiring fruit varieties, of which he had an impressively large collection, neither his stocks nor his prices are comparable to Eszterháza, not to mention that shipping from such a distance held great hazards for the buyers, because Liegel sent his plants at the buyer's risk.

Finally, the fourth and last item in the product range was the ornamental trees and shrubs. It was the least reliable in terms of steady income but its sales showed a definitive improvement over the years. It was in 1822 when ornamental trees were purchased by an individual for the first time: a princely musician at the Eisenstadt court, timpanist Michael Trimmel ${ }^{53}$ bought 200 black locust of two years old. His intentions are mysterious; perhaps he had some land and wanted to afforest it.

Sales of ornamental trees and shrubs started to increase in 1824. A nobleman, Pál Barthodeiszky of Répcelak tried the Eszterháza gardens on $11^{\text {th }}$ September when he bought some orangery fruits. He returned a month later on $4^{\text {th }}$ of October and purchased not only orangery fruits in a fairly substantial number for a household (180 sweet oranges and 65 lemons), but also many ornamental trees and shrubs, probably part of a landscaping project at his seat. It is even possible that Pölt furnished him with a design or at least with advice on a planting scheme. He bought plane trees, maples, biotas and many flowering shrubs, numbering nearly 400 specimens of almost twenty species.

Curiously, another nobleman from the neighbouring village of Szerdahely (today part of the township of Fertőszentmiklós), István Bezerédj Sr., purchased almost exactly the same products, but instead of Barthodeiszky's 25 pieces of most of them, he bought only 4 of each. Even the sequence of the plants follows Barthodeiszky's list, as though he wanted to create the same garden in miniature. This must have been due to Pölt's recommendation of garden plants and he again was probably responsible for a planting scheme, not only in choosing the plants but laying out or at least advising on the layout of the grounds. (There is no record of Anton Pölt's activity as a designer. However, his training and experiences must have made him capable of such tasks.)

The following year Barthodeiszky continued his custom purchasing more or less the same series of plants, with the difference that this time he bought 6 specimens of most of the species. Two more noblemen joined in to buy ornamental trees and shrubs in 1825. Pál Nagy of Felsőbük obtained two dozen horse-chestnuts and two sycamore maples, suggesting some kind of a formal layout, perhaps an avenue planting, while Count Viczay bought as many as 13 American plane trees besides 60 boxelder maples and 160 Siberian peashrubs. Count Viczay's purchase hints at a more informal planting project because plane tree was a favourite for English style landscape gardens, as opposed to horse-chestnuts that were fashionable in 
Baroque gardens in the preceding century.

Unit prices of ornamental trees and shrubs were significantly higher for these individual buyers than those used between the princely estates and offices (Table 2). Nevertheless, prices were apparently affordable at Eszterháza, and the convenient vicinity must have been another factor for the local landed gentry, who formed the sole customer group for this kind of product range. Despite the fact that there were many other noblemen among the higher ranking officers of the Esterházy estates, they are unlikely to have owned any substantial pieces of land to create a pleasure ground for themselves; these luxuries were left to those who had a country seat, however small the surrounding grounds might have been.

Prices differed somewhat less in the following year of 1825 . It is possible that dissimilarities partly or entirely originate from the various sizes or other quality differences of the plants; it is easier to select a smaller number of vigorous plants for an individual buyer than to deliver several hundred young specimens of the same species in superior quality for mass planting. And the Esterházy estates and particularly the Eisenstadt gardens demanded thousands of plants every year.

Already in the first year at his post, Pölt gave out 4500 different plants to the Eisenstadt garden and 800 black locusts to Csorna. The following year plant transfers were directed not only to Eisenstadt but also to Cinfalva (today Siegendorf in Austria), to Köpcsény (today Kittsee in Austria) and to the game park near Eisenstadt, totalling almost 6800 specimens. One year later, in 1823, Pölt gave out only around 1250 specimens, resulting in the least profitable year during his tenure. Demand was still high but the Eszterháza nursery was emptied by previous transfers and could not provide the several thousand specimens of species that were required for the Eisenstadt planting. The following year Pölt was again able to supply enough plants (nearly 3400 pieces) from the required species for the Eisenstadt pleasure grounds and some other princely offices in Süttör (today part of the township of Fertöd in Hungary) and Boldogasszony (today Frauenkirchen in Austria). Income more than tripled compared to the previous year but it was still less than half of the sale peak in 1822 (Table 1).

Finally, the last year produced an exceptionally large income for the Eszterháza gardens. The princely estates and offices demanded an unprecedented amount of trees and shrubs, somewhere around 9000 specimens. It was in large part destined to the Eisenstadt gardens, as usual, but some minor offices were also provided with plants. Furthermore, there were two princely town gardens, one in the Viennese Prater ${ }^{54}$ and one in Pozsony (today Bratislava) ${ }^{55}$ where some improvement of the gardens took place and plants were transferred there in hundreds. In addition to that, 1000 Ligustrum vulgare (common privet) and 800 Cornus sanguinea (common dogwood) from the Lés forest, that formed the groves and game park of Eszterháza, were dug up and transferred to the Pozsony town garden without any charge in October 1825. Income from other princely estates and offices in 1825 amounted to more than two and a half times more than in the previous peak year of 1822 .

Sales numbers clearly show that the plant transfers within the Esterházy realm were in large part responsible for the economic success of the Eszterháza gardens. With the exception of 1823 when the income was very low anyway, plant transfers significantly surpassed individual sales each year, bringing in 70 or even 75 per cent of the overall revenue.

\section{Analyses of Consumption Patterns: Destinations and Customers}

Contrary to their share in revenue, princely estates and offices contributed less to the geographical reach of the Eszterháza gardens than individual buyers. Plants or fruit were taken or sent to more than twenty towns from Eszterháza, but less than half of them coincided with other princely estates (Figure 4). Individual customers were sometimes also from the 
princely estates and offices, not to mention that there were often more buyers from the same town. Not surprisingly, most customers resided in Eszterháza itself, which developed into a small town during the second half of the $18^{\text {th }}$ century, along with the continual development of the princely manor and household, with many craftsmen and other, mostly nonagricultural, professionals who stayed there after the princely court moved to Eisenstadt. Almost half of the destinations lay within a $20 \mathrm{~km}$ radius, most of them small towns with the exception of Kapuvár that was one of the centres of the Esterházy estate organisations, and where Eszterháza itself belonged. An additional eleven destinations lay between 30 and 100 kilometres from Eszterháza. Among them were royal free towns like Sopron, Bratislava or Eisenstadt itself, but the others were small towns. The imperial capital of Vienna is more than 110 kilometres from Eszterháza with the aforementioned pastry baker as sole individual customer, and the furthest town is Komárom with its Franciscan monastery lying more than 140 kilometres away.

The further the towns lay, the fewer consumers Eszterháza reached, of course. It cannot be surprising either that those distant customers must have had some connection with either the princely household or Pölt himself. The Viennese pastry baker could have been connected to the princely palace in the imperial capital, while the Franciscan monk Father Farkas of Komárom might have just passed Eszterháza visiting the famous site and perhaps saw something to take home for his convent.

It seems that all the other customers lived close enough to Eszterháza to use it as the natural choice for plants. Orchard fruit was bought only within the $20 \mathrm{~km}$ radius. Orangery fruit and fruit trees were shipped by the buyers themselves, as there were only a few purchases per person on each occasion. The larger quantities of ornamental trees and shrubs for the pleasure grounds of nearby seats of the landed gentry were probably carried by serfs of the buyers, although they could have been taken by Esterházy personnel too. Naturally, the ornamental trees and shrubs for other princely estates were shipped with princely carriers.

There were around 130 different customers during these years. Only two of them made purchases in every year, the retired nobleman officer Dávid Horváth and the Esterházys' forest surveying engineer Ferenc Krausz. ${ }^{56}$ Around forty other consumers came back more than once to buy something, some of them almost every year. Not surprisingly, all returning customers were from within a 20 kilometre radius, with the exception of nobleman Pál Barthodeiszky of Répcelak who lived over 35 kilometres from Eszterháza and purchased plants in two consecutive years for his manor garden there.

Most of the customers were respected by Pölt for he called them Mister or Mistress. The ones without any honorific must have been peasants from the neighbouring villages as their simple Hungarian names also suggest. These latter ones were keen fruit tree buyers; some of them acquired quite many varieties. A certain István Pála, probably from the neighbouring Fertöszentmiklós as there were two other buyers with the same surname from that village, was a regular customer, buying fruit trees every year except 1824 . He must have been a well off person and also an avid fruit tree collector despite his probably humble origin as he bought sixteen different apple and pear varieties, in total 24 trees, and a further 30 walnut trees too. The estate physician Dr Neulinger also built up a choice orchard, having bought eleven different fruit varieties in the course of three years between 1823 and 1825, as did Rochus Offner from the adjacent village of Süttör, buying ten fruit varieties in three consecutive years between 1822 and 1824. Others favoured certain varieties, like Georg Piller and his wife who bought seven Salzburger pears, four Nagowitz pears and three Haber pears in 1822, 1823 and 1825. Nevertheless, the couple also purchased nine other pear and apple varieties and some walnut trees. In other cases couples were different in their customs. János Szücs only bought fruit and some young walnut trees in 1821 but his widow started to buy expensive pear varieties in the following two years. 
Even if different fruit tree varieties apparently had the same price range, the quality that one could afford was determined by one's income. In 1821 both the head of the estate, the nobleman György Lukinich and the manor caretaker Sándor purchased the same two types of apple trees, one of each cultivar. But whereas the modest spending of Sándor was 13x and $33 \mathrm{x}$, Lukinich spent on the same trees $2 \mathrm{Fl} 15 \mathrm{x}$ and $5 \mathrm{Fl}$ respectively, that is around ten times as much in both cases. Nevertheless, Sándor must have been a keen gardener for collecting eight different apple and pear varieties over the years, while Lukinich purchased six different varieties in 1821 and 1823. (The latter was transferred to Eisenstadt in 1824 and probably used the services of the local princely gardens there.) The differences in their acquisitions remained: all of Sándor's purchases stayed under 40x per tree whereas Lukinich never spent less on a tree than $2 \mathrm{Fl}$.

Some officers of the Esterházy estates were not interested in enhancing their gardens even if higher-ranking officers certainly had a garden adjacent to their residence. Bookkeeper Szabó was a regular customer but bought only fruit almost every year. The aforementioned gentleman officer, Dávid Horváth was the most enthusiastic fruit buyer at Eszterháza, regularly purchasing apricots, peaches, figs and even orangery fruit, but he also accumulated a collection of twelve different apple and pear varieties over the years.

\section{Conclusion}

Customs at the Eszterháza gardens outside this rather short period of five years are obscure and it is even doubtful whether the gardens offered fruit and nursery stock before and after Pölt's tenure, although it seems quite likely. Nevertheless, this narrow window opens up a hitherto entirely concealed period of the 'Hungarian Versailles' and its people. Eszterháza and its gardens were not isolated and only approachable by the prince and his guests but rather played an important role in local society, distributing horticultural knowledge along with plant material. The appreciation of the lesser known species and fruit varieties manifested in a wide circle of consumers of garden products who routinely returned there to learn and possess more of what Eszterháza was able to offer.

Nevertheless, the extent of this knowledge transfer and the appreciation or imitation of the princely household is limited. As explained before, the fruit varieties were not recently selected modern varieties but established cultivars. Even if they were possibly new for many of the buyers, regular purchases of the same varieties by certain customers point to other considerations: instead of propagating the acquired cultivars themselves, they rather trusted Pölt's horticultural expertise and bought the desired fruit trees on several occasions. In other words, horticultural craftsmanship did not seem to transfer as well as the pomological material.

It is doubtful whether Pölt or the prince had any intention to raise the quality of gardening in the vicinity of Eszterháza through the sale of choice plants. However, the prince had earlier sponsored a publication on the best French fruit varieties written by his court chaplain and printed at his princely press for the benefit of his fellow men, or at least this is what the grateful author claimed. ${ }^{57}$ Improving knowledge in agriculture and thus developing the homeland was a topic across the Germanic countries, including Hungary, in which orchards and fruit cultivation played a prominent role. ${ }^{58}$ Besides the efforts of enlightened monarchs in this respect, in part fuelled by their desire to raise income in their domains, some private individuals also felt the urge to help their fellow men: the foreword in the 1795 exhaustive pomology book on Mathias Rössler's Bohemian nursery already assured readers that the nursery was not purely for the satisfaction or financial profit of its owner but that he intended to enhance the fruit growing culture in his neighbourhood. ${ }^{59}$ The three seedsmen of Pest were also granted by a contemporary writer the noble task of improving the agriculture 
of their homeland through their businesses ${ }^{60}$ Eszterháza provided nursery material, unlikely to have been available in the region otherwise, to the general public. Distributing plant and gardening knowledge was thus an unassigned role that Eszterháza played nevertheless, creating a more varied landscape of plant consumption in the vicinity.

The product range of the Eszterháza gardens can eventually be divided into two main groups: nursery plants and fruit. These two are fundamentally different if the imitation of the aristocratic household is under investigation because the former indeed conveys knowledge transfer while the latter is related to culinary curiosities at the most. The garden fruits of Eszterháza were rather ordinary except for the harvest from the orangery that could undeniably count as luxury goods. Buyers of these fruits could perhaps experience some aspects of the lifestyle at a princely court ${ }^{61}$ Where the imitation of Eszterháza could really be applied is the purchases of ornamental trees and shrubs. Those gentlemen who bought a wide selection of ornamental plants were no doubt in pursuing the creation of their own luxurious retreat, similarly to their more wealthy peers. They even used the same plant range that was present in the Eszterháza pleasure ground, although they did not seem to have any other choice, namely there were apparently no other options for buying nursery plants nearby.

Plant consumption from the Eszterháza nursery thus fits well into the patterns of rivalry in collecting new species and varieties to impress visitors as Mark Laird has pointed out in his work on shrubberies. ${ }^{62}$ But while ornamental plantings of pleasure grounds at the seats of the local gentry levelled the division between the great landowner and the lesser nobility, sharing a single lifestyle just like in $18^{\text {th }}$ century England as Tom Williamson suggested, ${ }^{63}$ designed landscapes remained markers of social status in north-western Hungary, too. It is important to note that buyers of the ornamental species were always men of some rank. Fruit trees of the Eszterháza nursery, on the other hand, were bought by all members of society and thus were not suitable as objects of status; rather were they products of the commercial revolution of the plant trade. ${ }^{64}$ Günter Bayerl regards fruits to be among the 'descending cultural goods' ("sinkendes Kulturgut"), which found their way from the possession of the nobility to peasant households by the turn of the $19^{\text {th }}$ century. ${ }^{65}$ Whether the Eszterháza fruit trees were subjects of envy or rivalry among locals regardless of their class, it is difficult to say, but some consumers definitely appeared to be very concerned about collecting them.

Eszterháza had only a regional impact, not comparable to the famous commercial nurseries of Paris or London that sold their stocks across the continent and in effect spread the latest botanical novelties. The Esterházy princes also used their services to acquire new species, as explained earlier, and to be just as fashionable as any of their peers in the west of Europe. But those plants rarely found their way to Eszterháza, which was stocked with more established species and varieties, although many of them were still relatively unknown to the general public.

Proximity and personal connections helped Eszterháza to develop its status as a 'garden centre'. Mark Laird's study also shows that proximity and family connections (perhaps in addition to other personal connections) were the most significant factors in the spread of planting fashion. ${ }^{66}$ Nevertheless, price tags were perhaps matched to those of commercial nurseries in Vienna, Pozsony or Pest to be attractive for potential customers, but the relatively limited scholarship on the subject makes this difficult to prove. ${ }^{67}$ It is also not known how the Eszterháza nurseries attracted buyers from further afield; information about the products was probably spread by word of mouth. In that respect, awareness of the fruit tree auction days is the most unexplainable phenomenon as there were buyers from more distant towns too.

The Eszterháza estate gardening unit was only one department in the structure of the horticultural establishment of the Esterházy princes. It can rightly be assumed that other estate 
gardens played a similar role, and garden products were available to all members of society during this period. Further research could reveal how these departments of the princely household were connected, and even more interestingly, how they related to other nurseries of other aristocratic seats or commercial establishments. Some European nurseries had an impact over a thousand miles, whilst others only exercised influence locally; nevertheless, they were all part of a network of botanical and horticultural knowledge transfer, of which very little is known yet. The case of the Eszterháza nursery helps in understanding this network, but only further research will be able to discover its relevance as one of the nodal points in the European transfer of horticultural knowledge and material during the first half of the 19th century. 


\begin{tabular}{|c|c|c|c|c|c|}
\hline Product range/Income & 1821 & 1822 & 1823 & 1824 & 1825 \\
\hline Orchard fruits & $31 \mathrm{Fl} 571 / 2 \mathrm{x}$ & $14 \mathrm{Fl} 33 \mathrm{x}$ & $36 \mathrm{Fl} 1 \mathrm{x}$ & $9 F 126 x$ & $21 \mathrm{Fl} 4 \mathrm{x}$ \\
\hline Orangery fruits & $172 \mathrm{Fl} 37 \mathrm{x}$ & $48 \mathrm{Fl} 44 \mathrm{x}$ & $57 F 133 x$ & $85 \mathrm{Fl} 30 \mathrm{x}$ & $130 \mathrm{Fl}$ \\
\hline Fruit trees & $64 \mathrm{Fl} 34 \mathrm{x}$ & $168 \mathrm{Fl} 46 \mathrm{x}$ & $189 \mathrm{Fl} 23 \mathrm{x}$ & $63 \mathrm{Fl} 28 \mathrm{x}$ & $193 \mathrm{Fl} 54 \mathrm{x}$ \\
\hline $\begin{array}{l}\text { Ornamental trees and } \\
\text { shrubs (individual sales) }\end{array}$ & - & $12 \mathrm{Fl}$ & - & $97 F 143 x$ & $81 \mathrm{Fl}$ \\
\hline To individuals & $169 \mathrm{Fl} \mathrm{81/2x}$ & $244 \mathrm{Fl} \mathrm{3x}$ & $282 \mathrm{Fl} \mathrm{57x}$ & $255 \mathrm{Fl} \mathrm{57x}$ & $425 \mathrm{Fl} 58 \mathrm{x}$ \\
\hline To other princely estates & $436 \mathrm{Fl} 43 \mathrm{x}$ & $654 \mathrm{Fl} 35 \mathrm{x}$ & $108 \mathrm{Fl} 26 \mathrm{x}$ & $325 \mathrm{Fl} 30 \mathrm{x}$ & 1579Fl 59x \\
\hline Altogether & $705 \mathrm{Fl} 51 \frac{1}{2} \mathrm{x}$ & $898 F 138 x$ & $391 F 123 x$ & $581 F 127 x$ & $2005 \mathrm{Fl} 57 \mathrm{x}$ \\
\hline
\end{tabular}

Table 1: Annual incomes of the Eszterháza gardens by product range in gulden / forint $(\mathrm{Fl})$ and kreutzer / krajcár (x) between 1821 and 1825 


\begin{tabular}{|l|l|l|}
\hline Plants/Prices in $\mathbf{1 8 2 4}$ & Prices for individuals & Prices for Esterházy estates \\
\hline Syringa vulgaris & $4 \mathrm{x}$ & $3 \mathrm{x}$ \\
\hline Hibiscus syriacus & $12 \mathrm{x}$ & $6 \mathrm{x}$ \\
\hline Thuja orientalis & $18 \mathrm{x}$ & $10 \mathrm{x}$ \\
\hline Acer pseudoplatanus & $15 \mathrm{x}$ & $7 \mathrm{x}$ \\
\hline Caragana arborescens & $8 \mathrm{x}$ & $5 \mathrm{x}$ \\
\hline Colutea arborescens & $4 \mathrm{x}$ & $4 \mathrm{x}$ \\
\hline Ptelea trifoliata & $8 \mathrm{x}$ & $3 \mathrm{x}$ \\
\hline Laburnum anagyroides & $8 \mathrm{x}$ & $8 \mathrm{x}$ \\
\hline
\end{tabular}

Table 2: Price comparison of some nursery products in kreutzer / krajcár (x) in 1824 


\section{Illustrations:}

Figure 1: View of Eszterháza chateau from the garden in 1784 (from Beschreibung des Hochfürstliches Schlosses Esterháß im Königreiche Ungern, Preßburg: Anton Löwe, 1784)

Figure 2: The pleasure ground and the production gardens of Eszterháza in 1845, detail of a map by Ignác Szakonyi (EPA-BF, Baupläne, No. 332). The map is orientated southwards, thus the western gardens are on the right side.

Figure 3: The first entries in the 1821 ledger by the Eszterháza estate gardener Anton Pölt (EPA-BF, Eszterháza/Monbijou Gärten, 1821-1825)

Figure 4: Destinations of the Eszterháza garden products. The darker circle denotes a $20 \mathrm{~km}$ radius, the lighter one is at $100 \mathrm{~km}$ distance from Eszterháza.

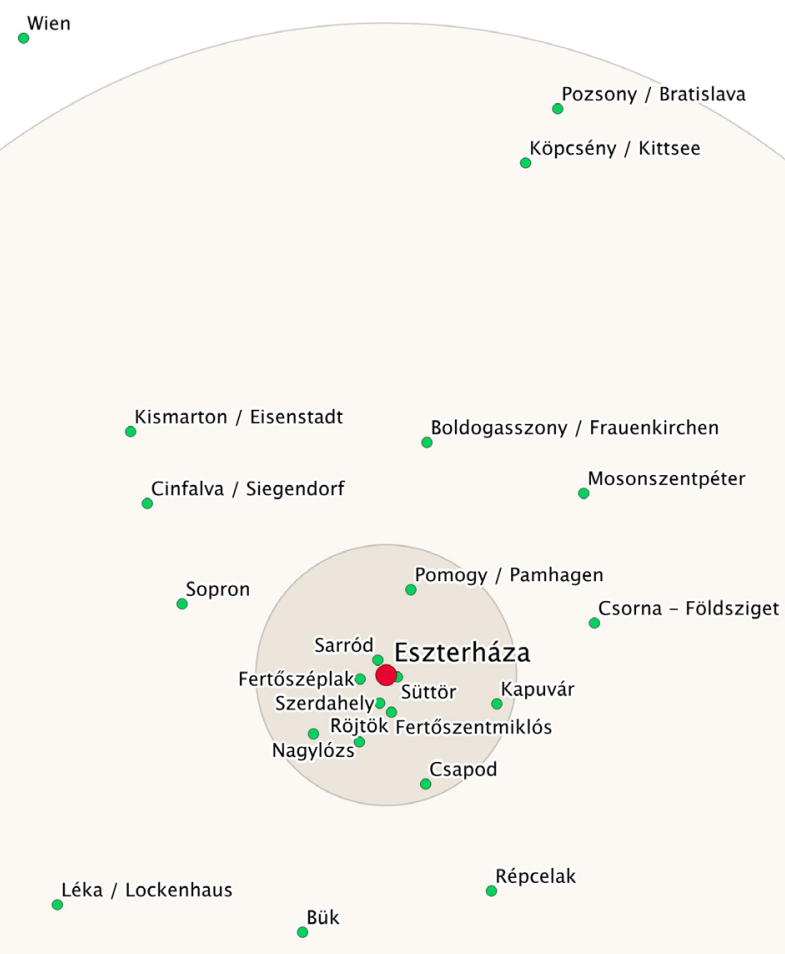


1 Scholarship on the history of the 18th century gardens of Eszterháza extended dramatically over the last fifteen years or so. The latest overview is Géza Galavics, 'Eszterháza 18. századi kertje' ['The $18^{\text {th }}$ century garden of Eszterháza'], in Kö kövön: Dávid Ferenc 73. születésnapjára, ed. Edit Szentesi, Klára Mentényi and Anna Simon (Budapest: Vince, 2013), Vol. II: 63-84, which - despite being a published form of a 2002 conference paper and thus tending to be less reliable - refers to all recent publications on the topic in its (updated) notes. Another recent overview focussing more on the development of the layout of the gardens is Kristóf Fatsar, Magyarországi barokk kertmüvészet [Hungarian Baroque Garden Art] (Budapest: Helikon, 2008), 103-111; and another one concentring on the most decisive design element of the ensemble is Kristóf Fatsar: 'Az eszterházai lúdlábsétány kialakulásának története' [The History of the Great Patte d'Oie of Eszterháza], 4D - Tájépitészeti és Kertmüvészeti Folyóirat, no. 3 (2006): 10-17.

2 Stefan Körner, Nikolaus II Esterházy und die Kunst: Biografie eines Manischen Sammlers (Wien: Böhlau, 2013).

3 The transformation of the gardens after the tenure of the 'magnificent' prince has been unfolded by Kristóf Fatsar, 'Átváltozások: Eszterháza nagy parterjének vázlatos története' [Metamorphoses: History of the Grand Parterre in Eszterháza], in MM XC: Tanulmányok és esszék a 90 éves Möcsényi Mihály tiszteletére, ed. Kristóf Fatsar (Budapest: BCE Tájépítészeti Kar, 2009), 77-90.

4 John Hooper Harvey, 'The Stocks held by Early Nurseries', The Agricultural History Review 22, no. 1 (1974): 18-35, here pp. 33-34.

5 John Hooper Harvey, 'Two early nurseries: Knowsley, Lancs. and Knutsford, Cheshire', Journal of the Chester Archaeological Society 59 (1976): 66-83, here p. 75.

6 Clemens Alexander Wimmer, 'Zur Entstehung von Baumschulen in Deutschland', in Frühe Baumschulen in Deutschland: Zum Nutzen, zur Zierde und zum Besten des Landes, ed. Sylvia Butenschön (Berlin:

Technische Universität Berlin, 2012), 15-44, here pp. 15-20.

7 Sylvia Butenschön, Heike Palm, and Jens Beck, 'Frühe Baumschulen: Produktion für das Schöne und das Nützliche', in Butenschön, Frühe Baumschulen in Deutschland, 7-13.

8 Harvey, 'Two early nurseries', 66.

9 Heike Palm, 'Die landesherrliche Plantage in Herrenhausen: Ein Instrument zur Förderung des Obstbaus und der Gartenkultur im Kurfürstentum Hannover', in Butenschön, Frühe Baumschulen in Deutschland, 69-109, here pp. 82-89.

10 Angela Pfennig, 'Landesverschönerung durch Obstbau in Neuvorpommern und Rügen: Die Baumschulen der Königlichen staats- und landwirtschaftlichen Akademie Eldena', in Butenschön, Frühe Baumschulen in Deutschland, 169-188, here p. 172.

11 Palm, 'Die landesherrliche Plantage in Herrenhausen', 75-76 and 79-80. In corresponding notes Palm refers to future analyses of the sources.

12 Palm, 'Die landesherrliche Plantage in Herrenhausen', 77 and 81-82.

13 Esterházy Privatstiftung Archiv, Burg Forchtenstein (in the following: EPA-BF), Domainendirektion Nos. 2018/1821, 2019/1821, 2020/1821 and 2024/1821.

14 EPA-BF, Domainendirektion No. 1903\&1904/1821.

15 Mathias Pölt was born in Ladendorf in Lower Austria and was employed at the end of 1775 as Princely Head Gardener at Eszterháza, see Franz Prost, 'Geschichte des Esterházyschen "Hofgartens” in Eisenstadt: Ein 
zusammenfassende Darstellung', in “Der Natur und Kunst gewidmet”: Der Esterházysche

Landschaftsgarten in Eisenstadt, 2nd ed., ed. Franz Prost (Wien: Böhlau, 2005), 43.; and also Hungarian National Archives, P 150, Fasc. 279 and P 154, Fasc. 26 (or Fasciculi 1156 and 1527 in the old system of the Prince Esterházy archives). When Prince Antal Esterházy came to power in 1790 he promised Pölt that if he acts and behaves to princely satisfaction, he would be given the Court Gardener position in Eisenstadt at the next vacancy (EPA-BF, Prot. 4745, f. 62). Matthias Pölt eventually became Court Gardener at Eisenstadt in August 1793, see Felix Tobler, 'Personal und Arbeitsorganisation im Eisenstädter Hofgarten (1800-1813)', Burgenländische Heimatblätter 69, no. 4 (2007): 204-213, here p. 206.

16 Tobler, 'Personal und Arbeitsorganisation', 207.

17 EPA-BF, Centraldirektion Nos. 2953/1804 and 4180/1805.

18 Tobler, 'Personal und Arbeitsorganisation', 209-210.

19 EPA-BF, Prot. 4735, f. 92.

20 Tobler, 'Personal und Arbeitsorganisation', 208.

21 Parish Register of Burials at Süttör, 1845-1871.

22 EPA-BF, Prot. 4875, f. 133.

23 EPA-BF, Domainendirektion No. 6825/1824.

24 EPA-BF, Prot. 4814, ff. 144; and Parish Register of Burials at Süttör, 1800-1844.

25 EPA-BF, Eszterháza/Monbijou Gärten, 1821-1825

26 EPA-BF, Prot. 5869.

27 EPA-BF, Domainendirektion Nos. 3780/1862 and 156/1863.

28 Fatsar, Magyarországi barokk kertmüvészet, 221-222.

29 Zsigmond Csoma, Kertészet és polgárosodás: Az európai szölészeti-borászati-kertészeti ismeretek oktatása, szaktanácsadása a Georgikonban és a Keszthelyi Uradalomban, a 18. sz. végétöl a 19. sz. közepéig (Budapest: Centrál Európa Alapítvány, 1997), 196.

30 Michael von Kunits, Topographische Beschreibungen des Königreiches Ungarn und seiner einverleibten Provinzen (Pest: Ludwig Landerer, 1824), 1: 19. Gyöngyösapáti lies next to Szombathely, also in Western Hungary, some $50 \mathrm{~km}$ south from Eszterháza; it is today part of the township of Gencsapáti.

31 Verzeichniss der vorzüglichsten Obstarten, welche im Garten und Baumschule von Apáty erzogen und gegen billige Bedingnissen abgegeben werden (Stein am Anger [Szombathely]: Franz Perger, 1823).

32 He was styled as such by John Claudius Loudon's The Gardener's Magazine 1 (1826): 480.

33 Annals of Natural History 3 (1839): 143.

34 EPA-BF, Domainendirektion No. 5855/1816.

35 John Claudius Loudon, Arboretum et Fruticetum Britannicum (London: Loudon, 1838), 1: 152-153. Loudon wrote this part of his book in 1835 as he often noted in the text, which makes a starting date around 1785. 
36 EPA-BF, Centraldirektion No. 1854/1821.

37 Loudon, Arboretum et Fruticetum, 79.

38 Loudon, Arboretum et Fruticetum, 139-140.

39 Tobler, 'Personal und Arbeitsorganisation', 210. However, there should be serious doubt whether this Noisette could be identified with Louis-Claude, who would have had to give up his nursery that he had just co-founded in 1806 to travel and stay in Eisenstadt for five years, although the one in Eisenstadt was also called Ludwig (in French: Louis) in the German-language records. Furthermore, the signature of that French Court Gardener is actually L. M. Noisette in the Esterházy papers. He worked in Eisenstadt together with his brother (Tobler, 'Personal und Arbeitsorganisation', 212; Stefan in the German records that should be Étienne in French), who was supposedly a brother of Louis-Claude, see François Joyaux, La Rose, une passion française: Histoire de la Rose en France 1778-1914 (Paris: Éditions Complexe, 2001), 107, and he was most probably the same person who later owned a nursery in La Queue-en-Brie, see Journal et Flore des Jardins (Paris: Rousselon, 1832), 29. Stefan/Étienne came to Eisenstadt only in 1811, but both Noisette brothers fell pray to the reduction of the Eisenstadt garden personnel in 1813, after which they went back to France (Tobler, 'Personal und Arbeitsorganisation', 213).

40 Fatsar, 'Átváltozások', 87-88.

41 EPA-BF, Prot. 5870. The inventory was drawn up for the takeover of the estate gardener position from Franz Pölt to Ludwig Engel, as explained earlier.

42 Botanical names in this paper were changed when necessary to bring them to their accepted current form: Pölt and the other gardeners in the service of Prince Esterházy used botanical names as they were in circulation in their time, no more valid in the botanical world. They also made mistakes in the writing that were also corrected.

43 EPA-BF, Baupläne No. 332, „Situations Plan / zur anlegung der neuen Exotischen-Baumschule / in Eszterház. - gezeichnet / im Jahre 1845 / von / Ignátz Szakonyi mp. / Ingenieur”

44 They were measured in meszely (Massl in Pölt's accounts that is a Germanisation of the Hungarian word; the German equivalent would be Seitel) and mérő (Metzen in the accounts) but these vary significantly according to the region where they were originally used. The two most likely candidates here are the Viennese and the Pozsony volumes for both units.

45 There is the strange entry of Fraxinus americana nigra in the records, combining the names of $F$. americana and F. nigra. It is less likely that the seeds were mixed of the two species but it rather refers to either one of them.

46 It is Sophora inermis eluitor in the records; the last word could easily be a misspelling, which are many in the plant lists. The previously mentioned mysterious Ratenus is another example of that.

47 Mosonszentpéter is today part of the township of Jánossomorja. Director of the Diocesan Archive of Győr, Ádám Vajk has helped me to ascertain the identity of the priests among the Eszterháza customers for which I am greatly indebted.

48 Prices are given in gulden (or forint in Hungarian, its - from Latin originating - symbol being Fl), which was called Convenzionsmünze (C. M.) in the Austrian Empire during this period. One gulden (forint) was divided into 60 kreutzer (or krajcár in Hungarian, its symbol being x).

49 Kunits, Topographische Beschreibungen, 126-133. The third seedsman, Leopold Hoffmann, did not sell nursery stock, although he started his business much later, at the late 1810s. Hassenstab's stock is said to have 
been from the nursery of the celebrated pomologist Johann Ludwig Christ (1739-1813) of Kronberg im Taunus, formerly in the Electorate of Mainz, during this time in the Duchy of Nassau.

50 The Viennese connoisseur pomologist Franz Josef Märter published the catalogue of his scientifically arranged nursery of fruit trees: Verzeichni $\beta$ der in der großen, systematischen Baumschule zu Hernals bey Wien cultivirten, und daraus zu beziehenden, ächten, feinen, französischen Tafelobst-Sorten (Wien: Schaumburg, 1805), but excuses himself for not giving his prices because of his small and not commercially motivated business; nevertheless, his prices would have been too much outdated by the 1820s anyway. Rössler's even earlier figures in his exhaustive Bohemian catalogue: Mathias Rössler, Sistematisches Verzeichniß aller in den Baumschulen der podiebrader Dechantey kultivirten Obstorten (Prag: Karl Barth, 1798), XXV-XXVIII, can be of little use for the same reason, although offering an interesting comparison for earlier stocks and prices.

51 Verzeichniss der vorzüglichsten Obstarten, 22. Sixteen years later a catalogue of a commercial nursery came out just over ten kilometres from Gyöngyösapáti that used the same phrasing, format and layout, leaving little doubt about their close but yet unexplained relationship: Verzeichniss der vorzüglichstes Obstarten, welche in dem Garten und der Baumschule des Joseph Wölfel in Güns gezogen, und gegen billige Bedingnisse abgegeben werden (Güns [Köszeg]: Carl Reichard, 1839); the set prices for high stem and dwarf trees were again left blank (p. 24).

52 Georg Liegel, Systematische Anleitung zur Kenntniß der vorzüglichsten Sorten des Kern-, Stein-, Schalenund Beerenobstes (Wien: Mörschner \& Jasper, 1825), 222-223.

53 Michael Trimmel was hired in October 1817 and served in the princely orchestra until the first day of 1828 when he was made redundant together with nearly half of the princely musicians in an attempt to rationalise the spending of the princely court, see Josef Pratl, Acta Forchtensteiniana: Die Musikdokumente im Esterházy-Archiv auf Burg Forchtenstein (Tutzing: Hans Schneider, 2009). I am indebted to the music historian János Malina for providing this information.

54 Prince Miklós II purchased a summer-house with a garden in the Prater of Vienna in 1823. It was sold in 1857 due to the financial crisis of the princely economy, and later named Waldstein Garden after its new owner. It was completely destroyed during WWII, see Richard Perger, Das Palais Esterházy in der Wallnerstraße zu Wien (Wien: Franz Deuticke, 1994), 8.

55 The garden palace in the outskirts of Bratislava was originally built for Count Aspremont from 1767 but Prince Esterházy purchased it for the fideicomissum in 1815, see Stefan Körner, "'Evviva il nostro prence, che il mondo fa stupir!”: Esterházy I. Miklós követsége II. József 1764. évi frankfurti koronázásán: szertartásrend, ünnepségek, mütárgyvásárlások', in Szentesi, Mentényi and Simon, Kö kövön, Vol. II: 25-52, here p. 46 and note 192. On the gardens of the palace see Fatsar, Magyarországi barokk kertmüvészet, 185186.

56 Personal data of the Esterházy officers were obtained from EPA-BF, Prot. 4814.

57 Joseph Theodor Colin, Gründlicher Unterricht, die besten französischen Obstbäume zu pflanzen, zu pflegen, und derselben Früchte zu benutzen (Eisenstadt: Johann Leopold Stotz, 1802).

58 Several chapters in a recently published collective volume on the German situation placed this phenomenon in the forefront: Landesentwicklung und Gartenkultur: Gartenkunst und Gartenbau als Themen der Aufklärung, ed. Sylvia Butenschön (Berlin: Technische Universität Berlin, 2014), also in the already cited other collective volume: Butenschön, Frühe Baumschulen in Deutschland.

59 Mathias Rössler, Pomona Bohemica oder tabellarisches Verzeichnis aller in der Baumschule zu Jaromirz kultivirten Obstorten (Prag: Calve, 1795), 7.

60 Kunits, Topographische Beschreibungen, 128-129. 
61 Marcus Popplow, 'Zum Stellenwart des Gartenbaus in der Ökonomischen Aufklärung des 18. Jahrhunderts', in Butenschön, Landesentwicklung und Gartenkultur, 35-48, indicates (on page 42) that fruits remained to be seen as luxury products of the nobility throughout the 18 th century in the contemoporary German literature on husbandry.

62 Mark Laird, The flowering of the landscape garden: English pleasure grounds, 1720-1800 (Philadelphia: University of Pennsylvania Press, 1999), 17. On the attitude of desiring a landscape garden see also Edward S. Harwood, 'Personal identity and the eighteenth-century English landscape garden', Journal of Garden History 13, no. 1-2 (1993): 36-48.

63 Tom Williamson, Polite Landscapes: Gardens and Society in Eighteenth-century England (Far Thrupp, Stroud: Alan Sutton Publishing, 1995), 109-113.

64 Neil McKendrick, John Brewer and J. H. Plumb, The Birth of a Consumer Society: The Commercialization of Eighteenth-century England (London: Hutchinson, 1983), 66.

65 Günter Bayerl, 'Zur Rolle von Nutzgärten und Obstbau in der absolutistischen Wirtschaftspolitik', in Butenschön, Landesentwicklung und Gartenkultur, 11-33, here pp. 23-29.

66 Laird, The flowering of the landscape garden, xvi. Laird also draws attention to the interaction between designers, clients, nurserymen in developing planting schemes, which can also hint at Pölt's advisory role in the purchases of ornamental plants by nearby landowners, as explained above.

67 The first British nursery catalogues with prices appeared in the north of the island around 1775, and prices were practically the same in York, Pontecraft or Newcastle upon Tyne, see Margaret Maddison, 'The Callenders, Eighteenth-Century Northern Nurserymen and Seedsmen', Garden History 33, no. 2 (2005): 210224, here p. 217. 